VASYLENKOV, V.E., and GUDZENKO, M.N.

National University of Bioresources and Use of Natural Resources of Ukraine, 12, Heroiv Oborony St., Kyiv, 03041, Ukraine,

+380 44527 8748, term_chair@nubip.edu.ua

\title{
EXPERIMENTAL DETERMINATION OF THE DOSE OF ENERGY RECEIVED BY SEED MATERIAL AFTER IRRADIATION BY ELECTRIC FIELD
}

Introduction. Maximum use of potential biological potential of seed material is among the ways to increase the production and to improve the quality of agricultural products. In view of the above, various methods of preseeding treatment of seeds of agricultural crops by means of electromagnetic fields are used. At the same time there is insufficient clarity of reproducibility of the results of radiation.

Problem Statement. However, the conventional methods for determining germination capacity require a wide range of equipment and materials and are time-consuming. Therefore, the search for new methods of pre-seeding treatment and the development of rapid calorimetric methods are promising directions of research.

Purpose. To study the effect of irradiation on seed material, by calorimetric methods.

Materials and Methods. To determine the caloric value of seed material, two batches of Scarlet barley seeds are taken, one of which is irradiated with an electric field. The caloric value of the grain has been determined using the calorimetric device B-08M, according to DSTU ISO 1928:2006.

Results. The results of quantitative indicators of temperature change of the irradiated and reference batch of barley grain have been presented in a graphical form to visualize the effect of irradiation. The analysis of results has shown that the non-irradiated seeds have a germination capacity of $82 \%$, while for the irradiated seeds this index is equal to $88 \%$. Respectively, their caloric value is $10842 \mathrm{~kJ} / \mathrm{kg}$ and $11985 \mathrm{~kJ} / \mathrm{kg}$, i.e. differs by $10.5 \%$. An experimental dependence has been established that to increase germination by $1 \%$ it is necessary to increase the caloric value of seed mass by approximately $1.83 \%$.

Conclusions. A 10-11\% increase in the caloric value of the seeds after irradiation indicates that the irradiation process is realized. The use of calorimetry methods can be recommended as a seed material irradiation quality control method.

Keywords: electromagnetic field, calorimeter, effect of stimulation, germination, irradiation.

Increasing the yield of agricultural crops, the production of a sufficient number of environment friendly agricultural products are extremely important issues both in Ukraine and throughout the world. The global problem of increasing population requires growing production of foodstuffs while the area of arable agricultural lands constantly decreases.

Citation: Vasylenkov V.E., and Gudzenko M.N. Experimental Determination of the Dose of Energy Received by Seed Material After Irradiation by Electric Field. Sci. innov. 2020. V. 16, no. 5. P. 63-70. https:// doi.org/10.15407/scine16.05.063 
A considerable part of yield (about $25-30 \%$ ) is lost because of poor quality of seeds [1]. More than $30 \%$ of seeds is unsuitable for sowing because of a low germination capacity and insufficient energy of germination [2]. The partial solution to this problem is introducing advanced, economically advantageous, energy-saving, safe technologies for stimulation of seeds before sowing. Now, there are many methods for treating the seed material. One of them is irradiation of crop seeds by electromagnetic field of different frequency and intensity [3, 4].

Such irradiation positively influences on germination capacity and height of plants. The early germination of seeds results in reduction of time of vegetation, whereas the stimulation of metabolic processes allows getting well-developed plants. All this increases harvest and helps to get it in a short term. The experimental data of Ukrainian [5-7], Russian [3, 4, 8-11] and foreign researchers [12-19] have testified to enhancing biological activity in the case of exposure to electromagnetic fields of different frequencies. From these studies it follows that the electromagnetic stimulation at the stage of pre-seeding treatment of seed helps increase the germination capacity of crop and vegetable seeds by $10-27 \%$, intensify their growth and, as a result, raise the productivity by $8-24 \%$. However, electromagnetic stimulation has not been widely used for the reason of insufficient manufacturability of its methods, considerable material resource consumption, and understudied ways and mechanisms of affecting biological objects, and insufficient reproducibility of results.

In studies [9, 10] Mrachkovska and Khnykina assume that the mechanism of influence of a lowintensity electric field is conversion of electric energy into heat and determine the energy of germination of seeds based on well-known GOST 12038-84 [20].

In [5] Bereka has established that conversion of electric energy into heat is the mechanism of influence of high-intensity electric field created by a direct current on seeds. He has worked out a method for norming and calculating the dose of energy absorbed by the seed mass. In addition to the quantification of electric energy conversion into heat according to well-known GOST 1203884 the author has proposed an algorithm (complicated mathematical apparatus) for computing the dose of energy absorbed by seed mass under the action of electric field.

In [21], Belyakov has stated that it is important to determine the germination capacity of crop seeds both for the purpose of sowing and storing. He has stressed that the conventional methods of determination of germination capacity require a wide set of equipment and materials and takes quit a long period. In his opinion, a promising direction of research is the development of optical luminescent methods with the use of photoluminescence analyzer, i.e. with the creation of a new device.

The most similar to our research in terms of technological approach are researches by Adamtsevich "Use of Calorimetry for Predicting Increase in the Strength of Rapidly Setting Cement Systems" and Fomina "Application of Methods for Calorimetry for Studying the Hydration of Portland Cement" [22, 23]. These works deal with the introduction of new methods for prediction of increasing strength of cement systems and substantiate new techniques for the determination of efficiency of admixtures that change the kinetics of hardening of cement-based materials without using standard cement strength control methods.

Fedotov and Ochirov [24] have studied a bioenergetic potential of wheat seeds. Bioenergetic potential has been estimated by measuring an electric signal from the treated seeds, using an electronic oscilloscope DSO 2100. Fig. 1 features fragments of voltage diagrams obtained with the use of computer oscilloscope DSO 2100, which show the condition of treated seeds (Fig. 1, $a$ ) as compared with the reference samples (Fig. 1, $b$ ) [24].

As one can see, the treated seeds have a bioenergetic potential. The reference samples are used 

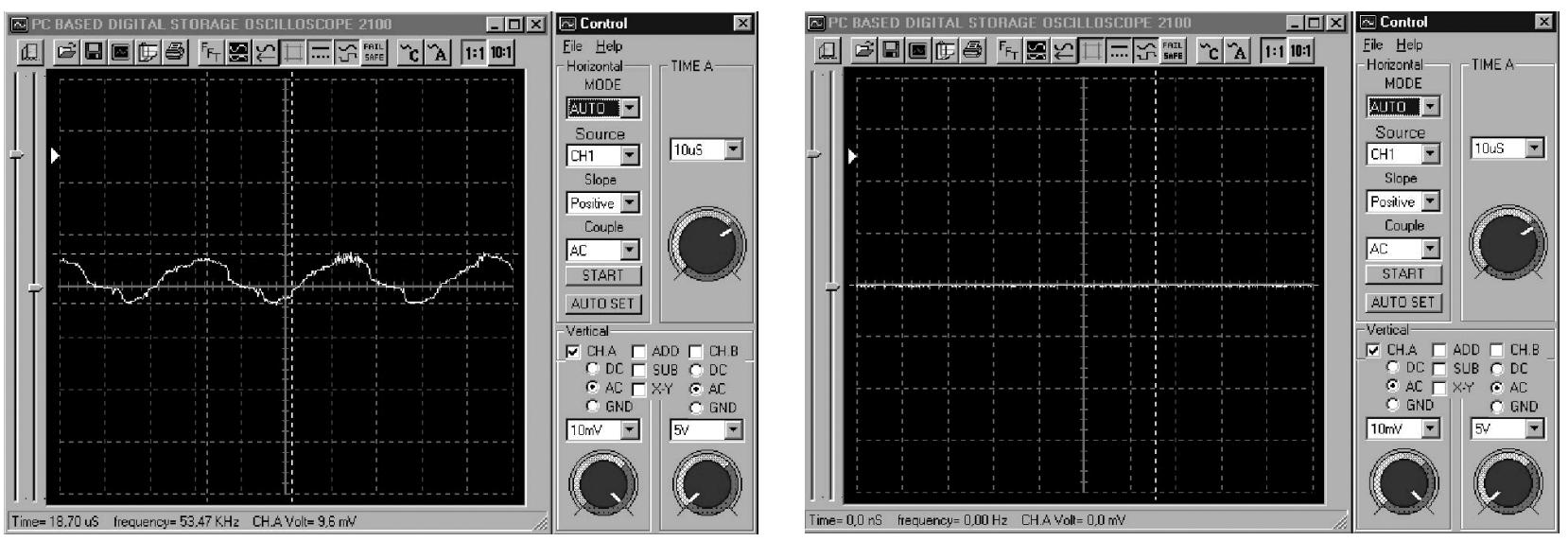

Fig. 1. Oscillograms of bioenergetic potential of wheat seeds in $24 \mathrm{~h}: a$ - treated seeds; $b$ - reference seeds

in order to show that the untreated seeds are in the state of rest. The only oscillogram is not sufficient to judge about efficiency of the method of pre-seeding treatment proposed by the authors. For verifying the efficiency of method it is necessary to link the bioenergetic potential to the germination capacity of seeds [24].

The authors of [24] have managed to show the efficiency of irradiation. In our research, we, we have gone further, namely, using the calorimetry methods we have quantified the caloric value of seeds before and after irradiation, presented the results as integrated curve of change in temperature and linked them to the germination capacity.

Because of specificity of seed material as biological object, it is difficult to choose a set of parameters that would describe the final result of electric field effect. We can talk about a generalized parameter (dose of influence D) that determines the effect of exposure to an electric field.

In our view, the most acceptable approach is the definition of dose as specific energy, i.e. amount of heat absorbed by unit of mass or volume of material. In addition, there shall exist a common approach to the determination of dose for different methods of physical influence. The mentioned approach to the definition of dose of treatment by electromagnetic fields as specific energy meets this requirement.
Thus, the analysis of academic literature and recent researches in this area have shown a lack of justification of technological process of irradiation of seeds by electric and magnetic fields of different intensity. So, [3, 5-10, 14-17] focus on the very technological process of irradiation and description of structure and configurations of irradiation devices. However, the influence of irradiation, namely the energy of seed germination is estimated «visually», by sowing radiation-exposed and the non-irradiated seeds, with further visual comparison. Therefore, the development of well-known calorimetry method, its adjustment for determination of dose of energy absorbed by seed material after exposure to an electric field of different intensity is a promising direction.

The purpose of this research is to use calorimetric methods while studying the results of irradiation of seed material by an electric field.

For determining the caloric value of seed material, the samples of non-irradiated and radiated grains of Scarlet barley are taken at the Bondarenko Department of Electromechanic and Electric Technologies at the National University of Bioresources and Use of Natural Resources of Ukraine. The irradiation parameters are as follows: intensity of the created field is $17.2 \mathrm{kV} / \mathrm{m}$, duration of exposure is $300 \mathrm{~s}$, and current density is $0.135 \mathrm{~A} / \mathrm{m}^{2}$. The parameters of the irradiation chamber are: 


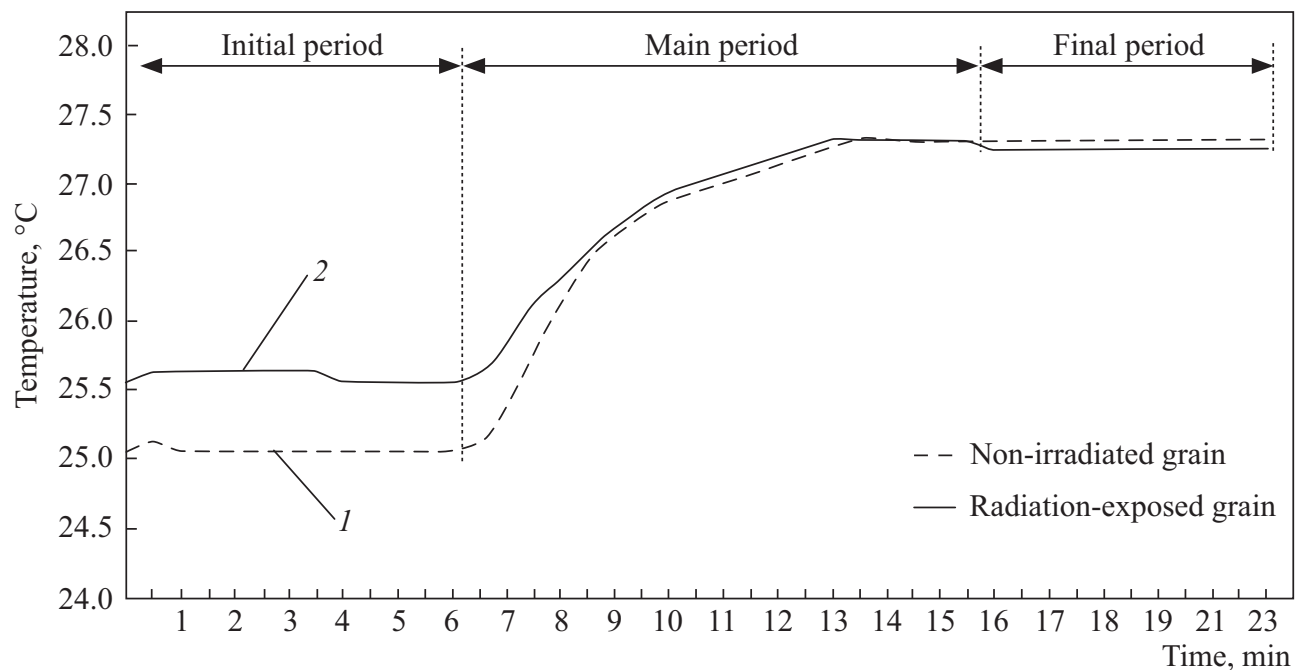

Fig. 2. Integrated diagram of change in temperature of radiation-exposed and non-irradiated barley seeds: 1 - non-irradiated seeds; 2 - radiation-exposed seeds

the electrode length is $0.1 \mathrm{~m}$, the distance between electrodes is $0.03 \mathrm{~m}$, the area of coverage of electrode is $0.08 \mathrm{~m}^{2}$. The first batch is the reference one, it is not exposed to radiation, while the second batch is irradiated by the electric field. The temperature of the seed mass is $20^{\circ} \mathrm{C}$.

Further calorimetry researches have been conducted at the Department for Heat and Power Engineering of the National University of Bioresources and Use of Natural Resources of Ukraine by means of the calibrated calorimetric device $\mathrm{B}-08 \mathrm{M}$ stabilized at a temperature of $25{ }^{\circ} \mathrm{C}$. Benzoic acid is used as reference substance.

Both the non-irradiated and radiation-exposed samples are placed in a crucible and burned in a calorimeter following the method statements $[25,26]$. The mathematical processing of the obtained data and graphic interpretation are made with the use of Microsoft Excel 2003, according to the method statement as described by the authors in [27].

The germination capacity of non-irradiated and radiation-exposed barley seeds has been determined in accordance with GOST 12038-84 [20].

Calorimetry is a complex of methods for measuring the amount of heat released or absorbed in different physical or chemical processes. This re- search deals with irradiating barley seeds by electric field and measuring the transformation of electric energy into heat (energy dose absorbed by the seed mass).

In [28], Askochenska states that the amount of water, in dry seed, hesitates from 4 to $14 \%$. For example, barley, even the driest one, contains $8-10 \%$ moisture that is needed for the formation of cells and tissue. Recently, in agricultural practice, these indexes have been tending downwards, as it is considered that the most optimal moisture content for storage shall not exceed 3-5\%. After electromagnetic stimulation, the seeds adsorb moisture and are in completely different state. A deviation from the state of rest is provoked for a substantial increase in the moisture content. For the germination, it is necessary to keep moisture content at the level of $30-50 \%$.

Exposure of seeds to an electromagnetic field of different intensity results in their heating, mainly, due to the presence of water molecules and dissolved ions in the cells. Under the action of HF electric field, water molecules and ions start moving faster and cause heating. A temperature is one of the factors influencing the effect of pre-seeding treatment of seed and the energy of germination. Proceeding from the Joule-Lenz law, the amount 
of released heat is proportional to resistance of seed mass, squared electric current, and time. If current varies with time, then it is possible to write down:

$$
Q_{c}=\int_{0}^{t} R_{s} i_{s}^{2} d t
$$

where $Q_{c}$ is amount of heat, $\mathrm{J} ; R_{s}$ is resistance of seed, ohm; $i_{s}$ is current through seed, A; $t$ is time of exposure, s.

Amount of heat that is attributed to time unit and unit of volume is the specific amount of heat $\left(q_{c}\right)$. Proceeding from the well-known relationships between current density $(j)$, intensity of electric field $(E)$, specific resistance, and specific conductivity, it is possible to write the expression for specific amount of heat as:

$$
q_{c}=j \cdot E,
$$

Table 1. Protocol of Thermometer Readings, by Periods, for Non-Irradiated and Radiation-Exposed Barley Seeds

\begin{tabular}{|c|c|c|c|c|c|c|}
\hline \multirow{2}{*}{$\begin{array}{c}\text { Measu } \\
\text { rement } \\
\text { num- } \\
\text { ber }\end{array}$} & \multicolumn{5}{|c|}{ Thermometer readings, by periods, ${ }^{\circ} \mathrm{C}$} \\
\cline { 2 - 7 } & $\begin{array}{c}\text { Initial period } \\
\text { irradia- } \\
\text { ted }\end{array}$ & $\begin{array}{c}\text { Main period } \\
\text { radia- } \\
\text { tion- } \\
\text { exposed }\end{array}$ & $\begin{array}{c}\text { non- } \\
\text { irradia- } \\
\text { ted }\end{array}$ & $\begin{array}{c}\text { Final period } \\
\text { rradia- } \\
\text { tion- } \\
\text { exposed }\end{array}$ & $\begin{array}{c}\text { non- } \\
\text { irradia- } \\
\text { ted }\end{array}$ & $\begin{array}{c}\text { radia- } \\
\text { tion- } \\
\text { exposed }\end{array}$ \\
\hline 0 & 25.06 & 25.56 & 25.06 & 25.56 & 27.31 & 27.31 \\
1 & 25.13 & 25.60 & 25.12 & 25.62 & 27.31 & 27.25 \\
2 & 25.06 & 25.62 & 25.31 & 25.81 & 27.31 & 27.25 \\
3 & 25.06 & 25.62 & 25.75 & 26.12 & 27.31 & 27.25 \\
4 & 25.06 & 25.62 & 26.12 & 26.31 & 27.31 & 27.25 \\
5 & 25.06 & 25.62 & 26.43 & 26.50 & 27.31 & 27.25 \\
6 & 25.06 & 25.62 & 26.62 & 26.68 & 27.31 & 27.25 \\
7 & 25.06 & 25.62 & 26.75 & 26.81 & 27.31 & 27.25 \\
8 & 25.06 & 25.56 & 26.87 & 26.93 & 27.31 & 27.25 \\
9 & 25.06 & 25.56 & 26.93 & 27.00 & 27.31 & 27.25 \\
10 & 25.06 & 25.56 & 27.00 & 27.06 & 27.31 & 27.25 \\
11 & 25.06 & 25.56 & 27.06 & 27.12 & 27.31 & 27.25 \\
12 & & & 27.10 & 27.18 & & \\
13 & & & 27.18 & 27.25 & & \\
14 & & & 27.25 & 27.31 & & \\
15 & & & 27.31 & 27.25 & & \\
16 & & & 27.25 & 27.31 & & \\
17 & & & 27.31 & 27.3 & & \\
18 & & & 27.31 & 27.31 & & \\
\hline & & & & & & \\
\hline
\end{tabular}

where $q_{c}$ is specific amount of heat; $j$ is current density; $E$ is intensity of electric field.

The majority of researchers determines the heat generation capacity of liquid biofuel and, in general, solid and liquid fuel theoretically, based on its elementary composition. To this end, the Mendeleyev formula is used [29]:

$$
\begin{aligned}
Q_{\mu}^{p}= & 81 C^{p}+300 H-26\left(O^{p}-S_{H}^{p}\right)- \\
& -6\left(9 H^{p}+W^{p}\right), \mathrm{kcal} / \mathrm{kg}
\end{aligned}
$$

where $C^{p}, H^{p}, O^{p}, S_{11}^{p}, W^{p}$ are gravimetric amount of carbon, hydrogen, oxygen, combustible sulfur and moisture in working mass of fuel, \%, respectively.

However, as the author states, this formula is suitable only for rough estimates. In the 1950s, at all coal-concentrating and briquette factories of the former USSR, there was an obligatory operation that was technical analysis of the quality of final products. One of main tasks was determination of caloric value of fuel or its heat-generation capacity in laboratory conditions, with the use of a calorimeter. Let us assume that the seed material is a sort of briquette and irradiation by electromagnetic field is an enrichment technique. In this case, the application of calorimeter is justified.

Table 1 contains protocols of thermometer readings, by periods, for non-irradiated and radiation-exposed barley seeds.

The integrated diagram of change in the temperature of radiation-exposed and non-irradiated barley seeds obtained using the method statement as described in [25] is shown in Fig. 2.

Table 2. Measurements of the Combustion Heat of Analytical Mass of Non-Irradiated and Radiation-Exposed Barley Seeds in Calorimeter

\begin{tabular}{|c|c|c|}
\hline \multicolumn{1}{|c|}{ Index } & $\begin{array}{c}\text { Non- } \\
\text { irradiated } \\
\text { barley seeds }\end{array}$ & $\begin{array}{c}\text { Radiation- } \\
\text { exposed } \\
\text { barley seeds }\end{array}$ \\
\hline $\begin{array}{l}Q_{8}^{a} \text { (heat of combustion (caloric } \\
\text { value) of analytical mass): } \\
\mathrm{cal} / \mathrm{g}\end{array}$ & 2593 & 2865 \\
$\mathrm{~kJ} / \mathrm{kg}$ & 10842 & 11985 \\
\hline
\end{tabular}


One can see that the temperature jump of the main period in the case of radiation-exposed seeds (position 2) is higher than that in the case of nonirradiated seeds (position 1), which has been confirmed by the results of measuring the combustion heat of analytical seed mass in a calorimeter (Table 2).

The germination capacity of the non-irradiated seeds is $82 \%$, while that of those exposed to radiation reaches $88 \%$. So, an increase in the germination energy is $6 \%$ [5].

The analysis of calorimetry method results (Table 2) has shown that the germination capacity of $82 \%$ corresponds to the caloric value $10842 \mathrm{~kJ} / \mathrm{kg}$, while $88 \%$ corresponds to $11985 \mathrm{~kJ} / \mathrm{kg}$. Hence, the caloric value of the radiation-exposed seeds is by $1143 \mathrm{~kJ} / \mathrm{kg}$ or $10.5 \%$ higher than that of the non-irradiated seeds. Proceeding from this, it has been established that in order to increase the germination capacity by $1 \%$, it is necessary to raise the caloric value of seed mass by approximate $1.83 \%$. Further research will deal with the germination capacity and caloric value dependence for other crops under various radiation doses.

1. The analysis of calorimetry method results has shown that the germination capacity of $82 \%$ corresponds to the caloric value $10842 \mathrm{~kJ} / \mathrm{kg}$, while $88 \%$ corresponds to $11985 \mathrm{~kJ} / \mathrm{kg}$. Hence, the caloric value of the radiation-exposed seeds is by $1143 \mathrm{~kJ} / \mathrm{kg}$ or $10.5 \%$ higher than that of the non-irradiated seeds. Proceeding from this, it has been established that in order to increase the germination capacity by $1 \%$, it is necessary to raise the caloric value of seed mass by approximate $1.83 \%$.

2. An increase by $10-11 \%$ in the caloric value of seeds after exposure to an electric field means that the process of irradiation as such is realized and can be recommended as means of control and an obligatory final operation for the technical analysis of the quality of irradiation of seed material, irrespective of irradiating device.

3. An increase in the caloric value of the radiation-exposed seeds enables improving the quality of substandard seeds up to the required quality standards.

\section{REFERENCES}

1. Berezin, O. V. (2010). Effective functioning of agricultural production. Economy of agrarian and industrial complex, 2, 26-31[in Ukrainian].

2. Adamen, F. (1997). State and trends of seed development in Ukraine. International agricultural Journal, 2, 49-50 [in Russian].

3. Andreychuk, V. K., Rednev, A. E., Potapenko, I. A. (2000). Electrophysical methods of presowing seed treatment of various agricultural crops. Application of electrical devices in the agroindustrial complex. Proceedings of KSAU, 381(409), 74-78 [in Russian].

4. Andreev, S. A. (1987). Installation for microwave treatment of seeds. (Candidate dissertation). Proquest Dissertation and Theses. Moscow [in Russian].

5. Bereka, A. M. (2010). Processing of seeds of agricultural crops in the electric field of high voltage. (PhD) (Technic.). Kiev [in Ukrainian].

6. Usenko, S. M. (2013). Disinfecting grain processing in an electrotechnical complex under the influence of an electric field of high tension. (Candidate dissertation). Proquest Dissertation and Theses. Kiev [in Ukrainian].

7. Petrovsky, A. M. (2013). Technology of front-loading stimulation with a high-frequency electromagnetic field. Eastern European Journal of Advanced Technology. 6/5(66), 45-50 [in Ukrainian].

8. Nizharadze, T. S. (2016). Theoretical substantiation of the application of physical methods of presowing seed treatment in the protection of grain cereals from diseases. ( $\mathrm{PhD})$ (Technic.). Samara [in Russian].

9. Mrachkovskaya, A. N. (2009). Influence of a weak electric current on seed quality of seeds and productivity of spring wheat. (Candidate dissertation). Proquest Dissertation and Theses. Kurhan [in Russian].

10. Rubtsova, E. I., Khnykina, A. G. (2009). The effect of a pulsed electric field on the energy of germination of soybean seeds. Mechanization and electrification of agriculture, 12, 26-27 [in Russian]. 
11. Statsyuk, N. V., Takur, K., Smetanina, T. I., Kuznetsova, M. A. (2016). Reaction of potato plants (Solanum tuberosum L.) of different varieties to the preplant treatment of tubers by a pulsed low-frequency electric field. Agricultural Biology, 3 , 360-366. doi: 10.15389 / agrobiology.2016.3.360rus [in Russian].

12. Aladjadjiyan, A. (2007). The use of physical methods for plant growth stimulation in Bulgaria. Journal of Central European Agriculture, 8(4), 369-380.

13. Aladjadjiyan, A. (2018) Use of physical factors as an alternative to chemical amelioration. Journal of Environmental Protection and Ecology, 4(1), 662-667.

14. Cakmak, T., Dumlupinar, R., Erdal, S. (2010). Acceleration of germination and early growth of wheat and bean seedlings grown under various magnetic field and osmotic conditions. Bioelectromagnetics, 31, 32, 120-129.

15. Pietruszewski, S., Martínez, E. (2015). Magnetic field as a method of improving the quality of sowing material: a review. International Agrophysics, 29(3), 377-389.

16. Marks, N., Szecówka, P. S. (2010). Impact of the variable magnetic field. Int. Agrophys., 24, 165-170.

17. Pietruszewski, S., Kania, K. (2010). Effect of the magnetic field on germination and yield of wheat. International Agrophysics, 24, 297-302.

18. Yinan, Y., Yuanc, L., Yongqing, Y., Chunyang, L., (2005). Effect of seed pretreatment by magnetic field on the sensitivity of cucumber (Cucumis sativus) seedlings to ultraviolet-B radiation. Environmental and Experimental Botany, 54(3), 286-294.

19. Martinez, E., Carbonell, M. V., Florez, M. (2002). Magnetic biostimulation of the initial growth stages of wheat (Triticum aestivum, L.). Electromagnetic Biology and Medicine, 21(1), 43-53.

20. GOST 12038-84 (2000). Seeds of agricultural crops. Methods for determining germination. Moscow [in Russian].

21. Belyakov, M. V. (2017). Optical luminescent analyzer germination of plant seeds. Innovations in agriculture, 2(23), 2-11 [in Russian].

22. Adamtsevich, A. O., Pashkevich, S. A., Pustovgar, A. P. (2013). Use of calorimetry to predict the growth of strength of cement systems of accelerated hardening. Engineering and Construction Journal, 3, 36-42 [in Russian].

23. Fomina, N. N., Kebedov, M. B. (2016). Application of calorimetry methods in the study of portland cement hydration. Technical regulation in transport construction, 1, 26-28 [in Russian].

24. Fedotov, V. A., Ochirov, V. D. (2017). Study of the bioenergetic potential of wheat seeds. Innovations in agriculture, 3(24), 239-242 [in Russian].

25. GOST 147-95 (ISO 1928-76). Solid mineral fuel. Determination of the highest calorific value and calculation of the net calorific value. Moscow [in Russian].

26. Shcherbakov, V. K. (1985). Methodical instructions to the laboratory work "Determination of the heat of combustion of solid fuel". Kiev [in Russian].

27. Vasilenkov, V. E., Gudzenko, M. N. (2015). Methodical approach and software in the analysis and processing of data obtained in calorimetric studies. Vestnik VIESKH, 4(21), 79-84.

28. Askochenskaya, N. A. (1979). Water regime in resting seeds. Biochemical and physiological studies of seeds, 1(4), 94-104.

29. Shvets, I.T., Golubinsky, V.I. (1963). General heat engineering. Kiev [in Russian].

Стаття надійшла до редакціï / Received 27.03.19 Статтю прорецензовано / Revised 11.07.19

Статтю підписано до друку / Accepted 16.09.19

\section{В.Є. Василенков, М.М. Гудзенко}

Національний університет біоресурсів і природокористування України,

вул. Героїв Оборони, 12, Київ, 03041, Україна,

+380445278748, term_chair@nubip.edu.ua

ЕКСПЕРИМЕНТАЛЬНЕ ВИЗНАЧЕННЯ

ДОЗИ ЕНЕРГІЇ, ОТРИМАНОЇ НАСІННЕВИМ МАТЕРІАЛОМ

ПІСЛЯ ОПРОМІНЕННЯ ЕЛЕКТРИЧНИМ ПОЛЕМ

Вступ. Максимальне використання потенційних біологічних можливостей насіннєвого матеріалу - це один із шляхів збільшення виробництва та підвищення якості сільськогосподарської продукції. Зважаючи на зазначене, застосовують різноманітні прийоми передпосівної обробки насіння сільськогосподарських культур електромагнітними полями. При цьому спостерігається недостатня чіткість відтворюваності результатів опромінення. 
Проблематика. Разом з тим, традиційні методи визначення схожості потребують широкого набору обладнання та витратних матеріалів, тривалих термінів дослідження, тому перспективним є пошук нових методів передпосівної обробки та розробка калориметричних експрес-методів.

Мета. Вивчення реакції насіннєвого матеріалу, а саме, його енергетичної цінності до та після опромінення методами калориметрії.

Матеріали й методи. Для визначення енергетичної цінності насіннєвого матеріалу було взято дві партії насіння ячменю сорту 'Скарлет', одну з яких піддавали опроміненню електричним полем. Енергетичну цінність зерна визначали за допомогою калориметричної установки В-08 М згідно ДСТУ ISO 1928:2006.

Результати. В графічній формі подано результати кількісних показників зміни температури опроміненої та контрольної партії зерна ячменю для візуалізації ефекту опромінення. Аналіз результатів показав, що неопромінене зерно має схожість $82 \%$, а опромінене - 88 \%, відповідно енергетична цінність першого становила 10842 кДж/кг, а другого - 11985 кДж/кг, тобто є на 10,5 \% вищою. Встановлено експериментальну залежність, що для збільшення схожості на 1 \% необхідно збільшення енергетичної цінності насіннєвої маси приблизно на 1,83 \%.

Висновки. Підвищення енергетичної цінності зерна на 10-11 \% після опромінення вказує на те, що процес опромінення відбувся, позитивний ефект зафіксовано. Використання методів калориметрії можна рекомендувати як спосіб контролю якості опромінення насіннєвого матеріалу.

Ключові слова: електромагнітне поле, калориметр, ефект стимуляції, схожість, опромінення. 